
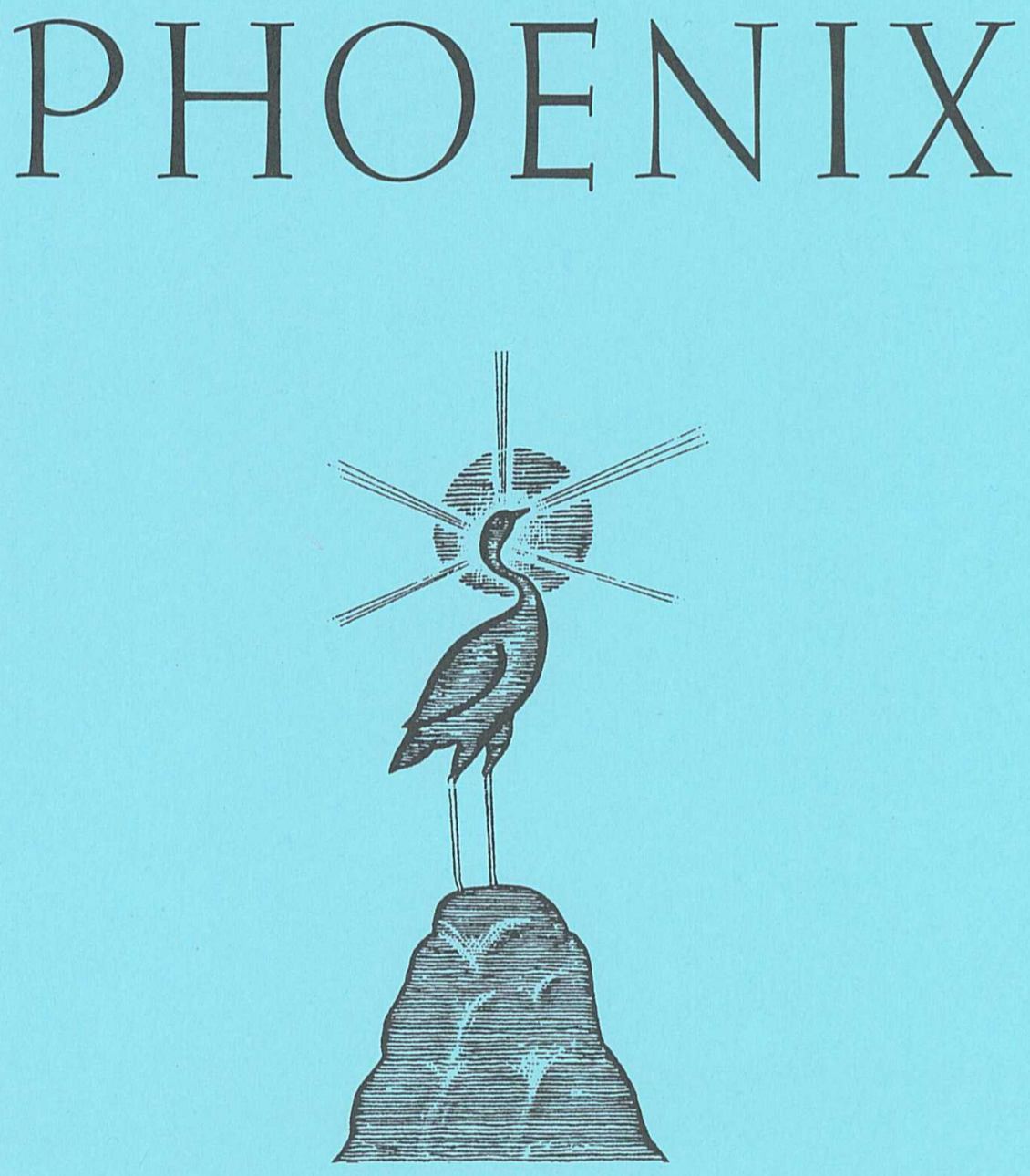

LXVIII No. 3-4, Fall-Winter/automne-hiver 2014 Classical Association of Canada Société canadienne des études classiques 


\title{
DRESS AND UNDRESS IN HERODOTUS' HISTORIES
}

\author{
Carmen Soares
}

$\mathrm{I}_{\mathrm{N} \text { this PaPer I will focus on how Herodotus uses the literary elements }}$ of "dressing" (in a particular way) and "undressing" (nudity) to interweave the themes of love, power, death, and gender identity in several of his emblematic short stories. In particular I will study the tales of Gyges and Candaules of Lydia (1.8-12) and that of Xerxes and Masistes of Persia (9.108-113), which are placed, respectively, at the beginning and the end of the Histories. I will then turn my attention to the story of Periander and Melissa (5.92 $)$, which comes precisely in the middle, and the episode of the massacre of Dareios' ambassadors in Book 5 (18-20). In all these episodes, "dressing" or "undressing" play pivotal roles.

I.

Whether intentional or not, the telling of two short stories with a similar theme at the beginning and at the end of the Histories is an important element that contributes to the cohesion of Herodotus' vast work. ${ }^{1}$ Specifically I am referring to the tales of Gyges and Candaules of Lydia (1.8-12) and that of Xerxes and Masistes of Persia (9.108-113). Both these tales hinge on the actions of a monarch who, driven by passion, commits acts of arrogance (bybris) violating socially accepted norms of behaviour. Acts of dressing and undressing provide visible proof of royal misconduct, leading to the shaming of a queen, who then punishes with death the real or imagined transgressor against her honour. As a consequence, elements of the monarch's private life are proven to have public and political implications.

In the prologue (1.1-5) we are told how one or more women are responsible (ai íía) for the hostility between Greeks and barbarians (i.e., between Asia and Europe; cf. 1.4.4) and how they are also the source of the misfortune brought

\footnotetext{
${ }^{1}$ Waters (1971: 82-85), constrained by the theory that no dramatic purposes were contemplated in Herodotus' narrative choices, refuses to recognize the similarities between the two tales; contra Wolff (1964), who first identified a narrative correspondence between the two stories. As this article shows, I follow Wolff in recognizing the unity of the Histories through the thematic and literary parallels of these two narratives. On the subject of the thematic unity of the episodes in question, see Herington 1991: 152-153; Blok 2002: 230-233; Desmond 2004: 31-40; Griffin 2007: 50. Griffiths (2007: 141), calls them "twin tales." For a detailed analysis of Xerxes' love episodes and Masistes' death, see Flower and Marincola 2002: 291-300. To better appreciate the issues that the definition of a "short story" entails, as well as the fundamental questions necessary to the understanding of their role in Herodotus' Histories, see Gray 2002 and Griffiths 2007.
}

PHOENIX, VOL. 68 (2014) 3-4. 
upon the Lydian king and the house of Xerxes' brother. Inflamed with loveCandaules for his wife (1.8.1), Xerxes first for his sister-in-law and then for his daughter-in-law, Masistes' daughter (9.108.1-2)—both barbarian monarchs

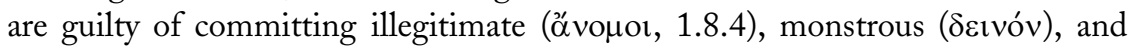
unfair ( $\alpha$ vó $\rho \sigma ı v, ~ 9.110 .3$ ) acts, or of urging others to commit them. Those who exceed the limits of what is considered reasonable commit the sin of hybris, and therefore, like tragic heroes, deserve to fall, according to the principle of retribution. This principle dictates that the offender incur the ultimate punishment of death for his criminal behaviour.

Readers of the Histories, however, are also informed from the beginning of Book 1 that not all bybristai are caught in the web of this archaic principle of justice: human interpretation also comes into play. That is, the severity of justice depends on the interpretation that individuals apply to the crime in question, the social and political power they have at their disposal to mete out punishment, and the rewards that the application of justice would bring to them.

In the story of Candaules' wife (1.8-12), the queen's honour is tainted when Candaules convinces his bodyguard, Gyges, to view with his own eyes the source of the king's pride: his possession of the most beautiful of all women. ${ }^{2}$ To show the nudity of one's wife to another man was considered by all barbarian peoples an act of anomia (lawless conduct), making the theme of undressing essential to the unfolding of the story. Candaules' guilt (as the instigator of the crime) and that of Gyges (as its agent) are rooted in the barbarian taboo against

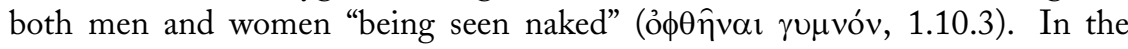
scene, the bodyguard shows his awareness of this taboo by initially resisting his monarch's request. He states that "the moment a woman takes off her clothes

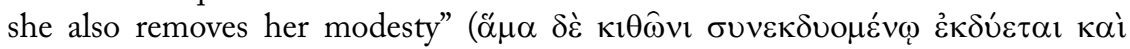

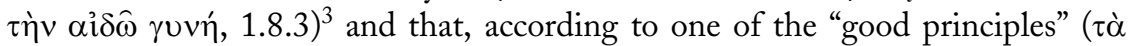
$\kappa \alpha \lambda \alpha$ ) inherited from the past, one "should only look at what was one's own"

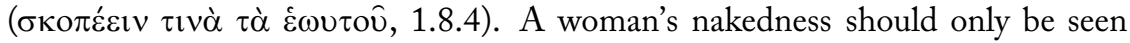
by her husband.

The conclusion of this story, however, shows that the application of justice has a certain degree of flexibility. As a principle of honour it depends on the social context: it is the result of public opinion regarding individual behaviour. The act of spying would not have been a crime had the queen not realized

\footnotetext{
${ }^{2}$ The frequency of verbs signifying "to look": if the verb $\theta$ cóoual is used, as Long (1987: 31) notes, it denotes the act of looking, understood as an offence $(1.8 .2,1.9 .2,1.10 .1,1.11 .3)$, while

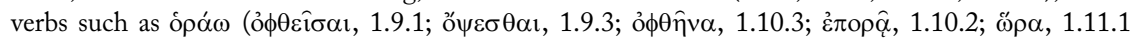
and 4; 'inns, 1.11.2) and $\sigma \kappa o \pi \varepsilon ́ \omega ~(1.8 .4)$ have a more neutral meaning. Travis (2000) compares the structure of Herodotus' version of Gyges' tale to the tragic version found in the papyrus fragment of a "Gyges Tragedy" (P. Oxy 2382). Such a distinction is based on the role that the act of looking has in the historian's text. See Anhalt 2008 for the persuasive power of visual evidence in Herodotus.

${ }^{3}$ The translations I am using are my own.
} 


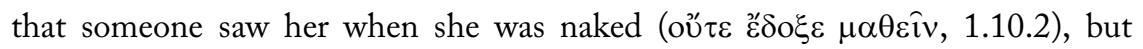
once she did, it became necessary for her to eliminate the risk to her reputation that the public revelation of this offence would have caused. Thus, the driving force behind the queen's behaviour is not passion, as it was in the case of her husband, but rather the wish to retain her position. She offers Gyges two options: murder the king and take his place, thus mitigating the charge of anomia by possessing the queen himself, or die, and thus cease posing a threat to the queen's reputation. In conclusion, although according to the barbarian nomos two people are guilty of violating the taboo of nudity (the one who plots it and the one who executes it), we see that only one of them pays for the offence with his life.

The same logic of forgiveness granted only to one of the offenders recurs in the bloody tale of Xerxes' love life. Here also we have a queen who feels she has been socially wounded, this time when her suspicions regarding her husband's adultery with her daughter-in-law are proven true and the transgression becomes

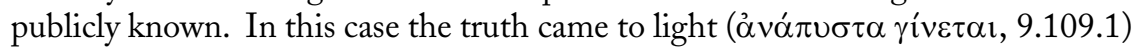
is through a piece of clothing: a remarkable cloak ( $\phi \hat{\alpha} \rho \varsigma)$ of great length and diverse colours, woven by the queen herself. This allusion to a festive costume is contrary to the episode in Book 1 where references are made to garments of daily use, such as the traditional tunic ( $\chi \imath \tau \omega$ v, 1.8.3) over which the woman placed an outer garment (i $\mu \alpha \dot{\tau} \tau \alpha, 1.9 .2 ; \varepsilon i \mu \alpha \tau \alpha, 1.10 .1) .{ }^{4}$ The importance conferred on a piece of lavishly embellished clothing is here reflected in the emotions of the wearer. Both Xerxes, to whom the pharos was first offered, and his lover, to whom by his own promise he was compelled to offer it as a gift, ${ }^{5}$ manifest either feelings of pride or happiness (9.109). For the monarch the pleasure was mostly internal (cf. the use of the past perfect tense of $\eta \delta \omega$ : iं $\sigma \varepsilon \varepsilon_{\varsigma}$, 9.109 .1 and 2); in Artaÿnte's case, ownership of the pharos produces extreme happiness $(\pi \varepsilon \rho \iota \chi \alpha \rho \eta ́ \varsigma)$, externalised through a desire to flaunt the gift

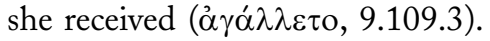

One wonders about the response of Herodotus' Greek audience to the tale of a barbarian king given a large, multi-coloured, and patterned ( $\left.\pi \circ \mathrm{o} \kappa i ́^{\prime} \lambda \mathrm{ov}\right)^{6}$ cloak. Despite the changes in antique dress codes since Homeric times, ${ }^{7}$ highquality home-produced cloth was seen as a significant status symbol. ${ }^{8}$ Clothing made from heavy, patterned fabric constituted a mark of social prestige, not only

\footnotetext{
${ }^{4}$ It must be noted that any of these three names can be associated with the generic meaning of "cloth," which I think is the one that Herodotus has in mind in this particular context. On the importance of the different garments mentioned in the text, see Cleland, Davies, and LlewellynJones 2007: s.v. chiton, heima, himation, and pharos.

${ }^{5}$ For the motif of the "fatal promise," cf. the episode of Ariston (6.62).

${ }^{6}$ For the meaning of $\pi$ orkí $\lambda \mathrm{o} \varsigma$, see Wagner-Hasel 2002: 22-25.

${ }^{7}$ For a synthesis of the transformations the Greek dress code suffered from Homeric times to the classical period, see van Wees 2010.

${ }^{8}$ In Attic drama clothing acts as a mark of recognition (Wagner-Hasel 2002: 25).
} 
because its manufacture demanded a great deal of labour, but also because its weight caused a constriction of movement in the wearer, producing a solemn effect. By giving her husband a cloak of exceptional beauty and richness, the Persian queen recalled two of the most famous Greek queens of the heroic past, Penelope and Helen, both known for their skill as weavers. ${ }^{9}$ The bloody and vengeful profile of Amestris, however, would have clearly set her apart.

While both stories focus on punishment through death for a criminal offense inflicted on the honour of a barbarian queen, the Persian Amestris, unlike the queen of Lydia, punishes an innocent victim. ${ }^{10}$ The principle that she uses to define the perpetrator is, however, similar to the one used by Candaules' wife: the offender is the one who engenders the offense, not his agent. Since she suspects the involvement of her sister-in-law in her husband's romantic liaison with his daughter-in-law, the punishment falls on the lover's mother, not on the lover herself. Once again the political repercussions of an act of a personal nature stand out. Upon seeing the brutality of his wife's punishment (her breasts, nose, ears, lips, and tongue had been severed with a knife, 9.112), the king's brother Masistes immediately starts plotting an uprising in Bactria, the province he rules. This in turn prompts Xerxes to capture and murder his brother, his nephews, and their respective armies (9.113). ${ }^{11}$ Although Herodotus does not explicitly mention it in the sentence that concludes the tale of the conspiracy arising in the Persian palace, the theme of personal acts having a political dimension forms one of the key pillars unifying his work. ${ }^{12}$

As we have just seen, the symmetry between these two dramatic logoi does not lie solely in the convergence of the themes. At the literary level, the repeated use of key words and sentences also helps to draw parallels between these two episodes bookending the Histories, forming, in Immerwahr's (1956-57: 313) formulation, a "skeleton structure" for the work. The predestination of misfortune and the inevitability of destiny (as woven by the Fates) inform both episodes. ${ }^{13}$ Herodotus uses a selection of similar concepts to signal the presence of Necessity, first in the episode of Candaules and later in that of Artaÿnte: ${ }^{14}$

${ }^{9}$ For Helen as weaver, see Hom. Od. 15.104-102, 2.339, 21.51-52, Il. 6.288-290; for Penelope, Hom. Od. 2.106-109, 24.141-145.

${ }^{10}$ See Flory (1987: 41-47) for the motif of the "intelligent and vengeful woman," for example, Tomyris, Nitocris, and Pheretime; cf. Albaladejo Vivero 2007; Flower 2007: 283-284.

${ }^{11}$ These "cleansings" aimed at annihilating an opponent and his natural supporters, his children, form a true power statement of the barbarian kings; see, for example, Dareios against Intafernes (3.119) and the Scythian king against the diviners (4.69).

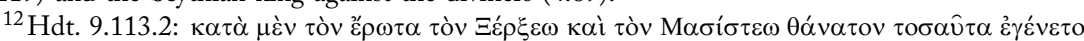
("such is the story of Xerxes' love and Masistes' death"). On the subject of the political interpretation of the story of Masistes' wife, see Dewald 1997: 68-70 and Chiasson 2003: 24. For an interpretation identifying the special role that clothing assumes in this episode, see Sancisi-Weerdenburg 1983: $27-30$.

${ }^{13}$ Long (1987: 179) identifies similarities between the two episodes.

${ }^{14}$ On the vocabulary of necessity in the Histories, see Munson 2001. 


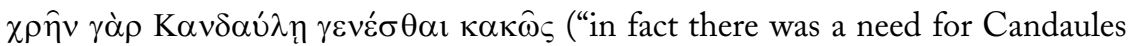

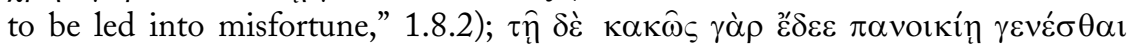
("in fact there was a need for her to be led into misfortune as well as all of her family," 9.109.2).

Further thematic convergence is produced by Herodotus' recurring use of words with the same root. These key words are:

a) "to need," expressed through words formed by the roots $\delta \varepsilon-, \alpha^{\alpha} v \alpha \gamma \chi-$, and $\chi \rho \alpha-$ : an old precept dictates $(\delta \varepsilon \hat{\imath})$ that each person should only look at what was his (1.8.4); Gyges' needs to either murder Candaules or lose his

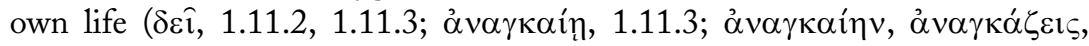
1.11.4; है $\delta \varepsilon \varepsilon, 1.12 .1)$;

b) "to offer" ( $\delta i \delta \omega \mu \iota)$ : the Lydian queen offers $(\delta i \delta \omega \mu \mathrm{l}, 1.11 .2)$ Gyges the choice of two options and gives him $(\delta \circ \hat{v} \sigma \alpha, 1.12 .1)$ the dagger with which he will kill her husband; Xerxes presents $(\delta 1 \delta 0 \hat{i}, 9.109 .1)$ Artaÿnte with the cloak,

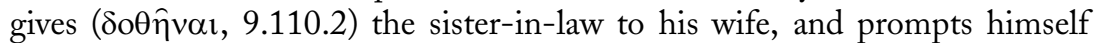
to give $(\delta i \delta \omega \mu 1,9.111 .2)$ to Masistes one of his daughters as his wife;

c) "to persuade" ( $\left.\pi \varepsilon^{i} \theta \omega\right)$ : Candaules wants to persuade $\left(\pi \varepsilon^{i} \theta \varepsilon \sigma \theta \alpha\right.$, 1.8.2) Gyges of his wife's singular beauty; Gyges is persuaded ( $\pi \varepsilon i \theta o \mu \alpha \iota, 1.8 .4 ; \pi \varepsilon 1 \theta$ ó $\mu \varepsilon v o \varsigma$,

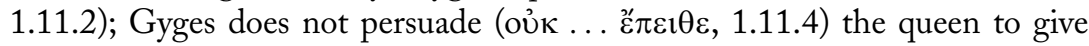
up the idea of inflicting punishment through death, the death of the king or his own; Xerxes does not persuade (oủ ... ع̋ $\pi \varepsilon 1 \theta \varepsilon$, 9.109.3) Artaÿnte to wish for any gift other than the royal cloak;

d) "to understand/know" ( $\mu \alpha v \theta \alpha ́ v \omega, \pi v v \theta \alpha \dot{\alpha} v \mu \alpha 1)$ : men know ( $\mu \alpha v \theta \alpha \dot{v \varepsilon} v v$, 1.8.4) the good principles they must follow; Candaules' plan, in order to be successful, depends on his wife's being unaware $(\mu \eta \delta \dot{\varepsilon} \mu \alpha \theta \varepsilon \hat{\varepsilon} v, 1.9 .1)$ that she is being looked at naked by a man; she hides the knowledge (oú $\varepsilon \varepsilon$ है $\delta \circ \xi \varepsilon$ $\mu \alpha \theta \varepsilon i v, 1.10 .3)$ of what her husband has done to her; Amestris gets to know ( $\pi \cup v \theta \alpha$ ó $\tau \alpha \_1,9.110 .1$ ) that her daughter-in-law is the keeper of the royal cloak, but that knowledge ( $\mu \alpha \theta 0 \hat{\sigma} \sigma \alpha, 9.110 .1)$ elicits no resentment against her; Xerxes withdraws the initial offer he made to Masistes of giving him his daughter in marriage in order that he may learn ( $\mu \alpha \dot{\theta n \varsigma}, 9.111 .5)$ to accept only what he is given; as soon as he gets to know ( $\pi \cup \theta$ ó $\mu \varepsilon v o \varsigma, 9.113 .2)$ his brother's subversive plans, Xerxes orders his execution;

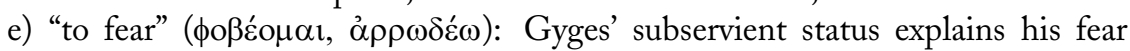

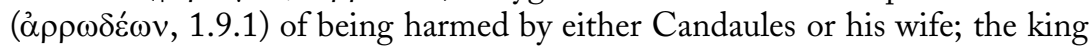
secures his collaboration by convincing him not to fear ( $\mu \grave{\eta} \phi \circ \beta \varepsilon \hat{v}, 1.9 .1$ ) any harm from either side; Xerxes tries to dissuade his daughter-in-law from

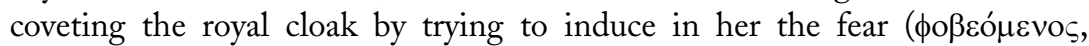
9.109.3) of a violent retaliation by his wife.

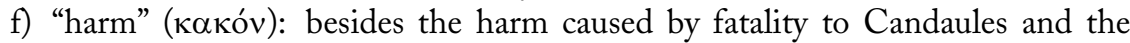
household of Masistes (cf. above, 1.8.2 and 9.109.2), Gyges also feels threat-

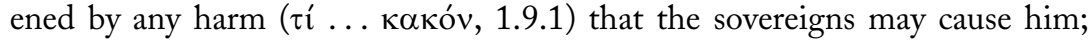


Masistes, irked by the queen's behaviour and the king's collusion, decides to cause the monarch, his own brother, great harm ( $\pi$ oıń $\sigma \omega v \tau \dot{\alpha} \mu \varepsilon \dot{\gamma} \gamma \sigma \tau \alpha$ $\kappa \alpha \kappa \hat{\omega} \vee \beta \alpha \sigma \imath \lambda \varepsilon \dot{\alpha} \alpha, 9.113 .1)$

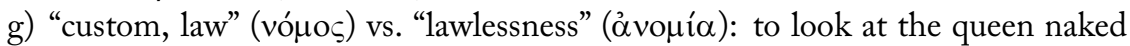
is an act that Gyges considers to be illicit ( $\alpha$ vó $\mu \omega v, 1.8 .3)$ and one that the victim herself considers equally as an act contrary to custom ( $\pi$ oเท́ $\sigma \alpha \nu \tau \alpha$ oủ

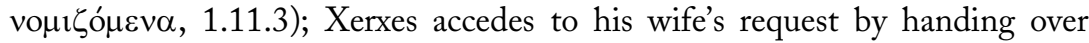

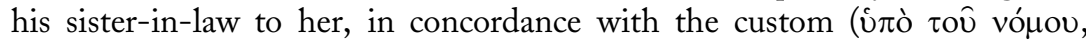
9.111.1) that requires the king's compliance with any request made to him during the celebratory festivities on his birthday;

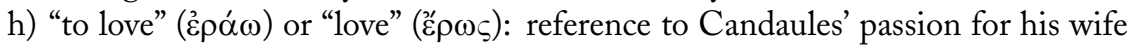
and that of Xerxes for other women respectively is made at the beginning of

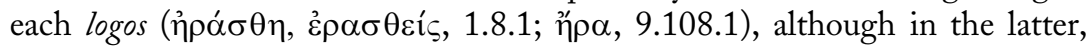
the association of the verb "to love" with "to happen to" ( $\tau \cup \gamma \chi \alpha \dot{v} \omega)$ reveals

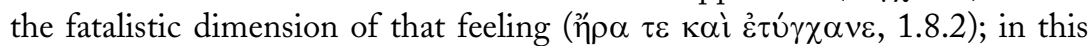
story the noun "love" is also the last word (9.113.3), conferring a cyclic effect to the story and thus providing a sense of unity to its subject;

i) "to dress, to adorn (with clothes)" (

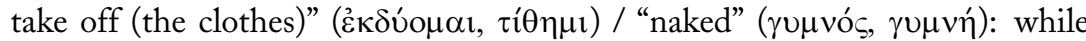
the intrigue initiated by Candaules emphasises the act of taking off clothes $(1.8 .3,1.9 .2,1.10 .1)$ and the subject of nudity $(1.8 .2,1.8 .3,1.10 .3,1.11 .3$, 1.11.5), the opposite happens in Xerxes' fatal love story, where the focus lies in the act of putting on clothes $(9.109 .1,9.109 .3)$. Note that the parallel between the two logoi is only thematic, considering the fact that Herodotus uses different specific terms for clothes and dressing in each scene.

The analysis of these two short stories demonstrates the strategic placement by Herodotus of acts of dressing and undressing in the Histories. The story of the Lydian queen at the beginning functions as a kind of incipit to the nine books; the story of the Persian queen, near the end of the text, appears as a coda. The author ties these episodes together through the use of the same patterns at different moments in his work, allowing us to recognise their status as leitmotifs. He further includes, in the exact middle of his work, an episode with a theme similar to that of the opening and ending logoi analysed above.

II.

The story of the Greek tyrant Periander is the story of a husband's excessive and improper love for his dead wife, Melissa. He violated social norms by having sex with her corpse $(5.92 \eta 3)$, then committed the additional transgression of forcing all the Corinthian women and their female slaves to disrobe to appease her ghost. In this he was following a command of the oracle of the dead, and interpreting a lament by his wife's ghost of being cold and naked as an order to complete her funerary rites by burying her corpse with burnt clothes ( $\tau \hat{\omega} \vee \gamma \gamma \alpha$ oi 


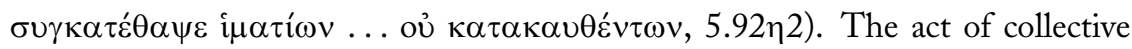
nudatio was intended to appease her anger and to persuade her to reveal the location of hidden treasure buried by a friend. Here we see repeated both the elements of undressing (forcing the Corinthian women to disrobe) and dressing (providing clothes for a naked ghost).

A deeper understanding of the nudatio scene as described in $5.92 \eta 3$ can be reached if we consider that the story of Periander's dead wife reproduces leitmotifs also seen in the scenes of Candaules' wife and Xerxes' lover. Although from a cultural perspective the present narrative unfolds within a Greek context, in contrast to the barbarian royal households of Lydia and Persia, the behaviour portrayed in the Periander episode reflects a similar set of values. The same ethical values are at play, indicating a shared conclusion: indulging in excessive behaviour which transgresses the established nomos (vó $\mu$ ov $\pi \alpha ́ v \tau \omega \nu \beta \alpha \sigma \iota \lambda \varepsilon \dot{\alpha} \alpha$, 3.38.3) is typical of tyrannical political rulers, Greek or barbarian. ${ }^{15}$ Candaules, Xerxes, and Periander, despite their cultural differences, have very similar moral and behavioural characteristics, and their stories as told by Herodotus share some key narrative elements:

a) Periander becomes the author of an act of anomia by ordering that all the women of the city, both free and slave, should be seen naked. This echoes Candaules' transgression in Book 1. The victims of the tyrant's anomia are women: Candaules' wife has her nakedness exposed; Masistes' wife and the women of Corinth are used to correct a fault of their master.

b) The wife of the absolute ruler assumes the role of the "intelligent queen." In the story of Candaules' wife, she knows that her nudity has been seen. Likewise, in the story of Xerxes, Amestris knows that her husband has been unfaithful. The ghost of Melissa is aware that her husband buried her with improper funeral rites and knows the location of hidden treasure that he wishes to find. All three queens act on the knowledge they possess. Candaules' wife has Gyges murder her husband; Amestris exacts revenge on Masistes' wife; the ghost of Melissa forces her husband to correct his initial failure to perform the proper funeral rites in order to reveal (through signs or words:

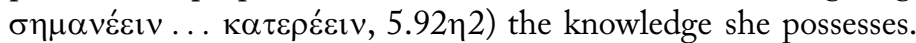

c) A supernatural entity influences an individual's impulse towards an act of transgression: in the stories of the Lydian and Persian queens it was Necessity who impelled both Gyges and Xerxes' lover to act as they did, and in the Greek tyrant's story it is Melissa's ghost ( that performs this role.

\footnotetext{
${ }^{15}$ For nomos as a principle of historical causality in Herodotus' work, see Evans 1965 . On the meaning of the word and the development of the concept in classical Greece, see Ostwald 1969: 1-54 and de Romilly 1971: 51-71. Humphreys (1987) explores the concept of nomos specifically in Herodotus' work.
} 
d) There is an association between the tyrant and the indulgence of excessive passions. Periander "joined [his wife], when she was already a corpse" $(5.92 \eta 3),{ }^{16}$ then violated social convention further by forcing the Corinthian women to disrobe. Excessive pride caused Candaules to expose his own wife's nudity and Xerxes indulged in an orgy of killing in the aftermath of his adultery being discovered.

Herodotus puts Periander's story into the mouth of Socles, the Corinthian ambassador. In this speech we find his main motivation for telling the story of the forced nudity of the Corinthian women and slaves: it functions as an enlightening example of the despicable nature of tyranny. ${ }^{17}$ Herodotus already reflected on this theme in Book 3 (80-83), where he has the Persian Otanes identify three negative characteristics inherent to the despotic ruler: "excess"

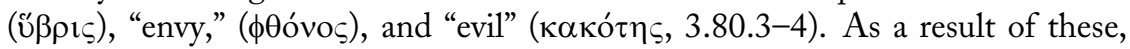
the most abominable crimes ( $\tau \dot{\alpha} \mu \varepsilon \dot{\gamma} \gamma \sigma \tau \alpha)$ become commonplace in the tyrant's behaviour. All these crimes-the subversion of traditional values (vó $\mu \alpha 1 \alpha \tau \varepsilon$

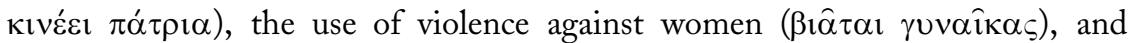

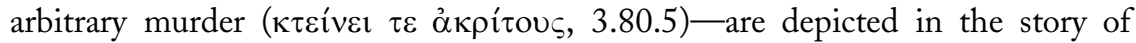
Periander and Melissa. The acts of anomia committed by the tyrant occur in both the personal and the public sphere, with a clear chain of causation. Periander's crime against the modesty of the Corinthian women (the public dimension of the transgression) was the only way the tyrant could resolve two personal problems (appeasing his wife's ghost and locating hidden treasure). Gathered here are all the crimes attributed by Otanes to the prototype of the tyrant, namely: violence against women (not only the Corinthian women but also Melissa, with whom Periander had intercourse after her death, cf. 5.92ๆ3), as well as hybris and kakotes. The death of Melissa, although not narrated in detail, ${ }^{18}$ can be seen to correspond to the abuse of power that leads to the death without trial of one who has displeased the tyrannos, and Periander is clearly motivated by greed in his consultation of the oracle of the dead ( $\tau$ ò

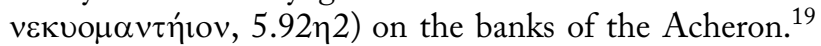

I will now focus on the way in which the subject of clothing in the present episode assumes the role of catalyst in the plot. As in the previous episodes,

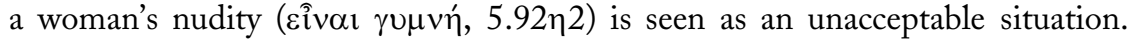

\footnotetext{
${ }^{16}$ On the subject of the Greek belief that the corpse possesses a miasma that pollutes those who come in contact with it, see Garland 1985: 38-47.

${ }^{17}$ Moles (2007: 256) also sees Socles' reflections on tyranny as the expression of Herodotus' opinion on this matter, despite not drawing a parallel with the words of the Corinthian and 3.80-83. Many scholars have considered in detail the well-known "Persian Debate," revealing the programmatic importance it has for the interpretation of Herodotus' political narratives. See Lateiner 1984; Rocha Pereira 1990; Pelling 2002; Soares 2014.

${ }^{18}$ Cf. Diog. Laert. 1.94 with Gentili and Prato 2002: 20-21.

${ }^{19}$ Cypselus, Periander's father, also had a habit of greed, which he exhibited by stripping Corinthian citizens of their possessions (5.93\&2).
} 
The rectification of the original act of anomia committed by Periander-having Melissa buried wearing unburnt and thus unsuitable clothes ${ }^{20}$-is accomplished through a ritual which has features similar to the previous transgression. According to the message of the condemned ghost, if burnt clothes will end her suffering in the grave, a living person will have to furnish her with clothes to keep her covered and warm. As the wife of a ruler, her clothing and accessories must match her social status, ${ }^{21}$ which is why Herodotus emphasizes that Perian-

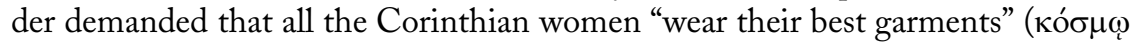
$\left.\tau \hat{\omega} \kappa \alpha \lambda \lambda i \sigma^{\sigma} \tau \omega \chi \rho \varepsilon \omega \mu \varepsilon v \nu \alpha\right),{ }^{22}$ as if they were dressing for a festive occasion ( $\omega \varsigma$

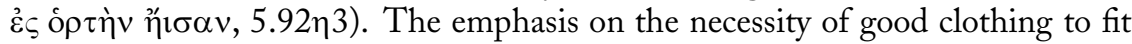
Melissa's status constitutes another topos relating to dress, establishing a parallel between this scene and the one of Artaÿnte's wearing Xerxes' beautiful cloak.

The scene of collective undressing also has an important feature in common with the episode involving the nudatio of Candaules' wife: the male voyeur. Like the Lydian queen, the Corinthian women who were forced to take off

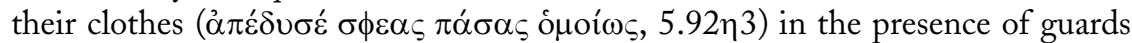
were not supposed to be aware of them (hence the opinion that Periander

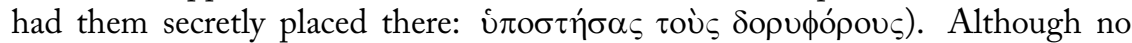
reference is made here to the shame felt by the women for being looked at naked (contrary to the episode involving the Lydian queen), this is an anomia that cannot be ignored in the analysis of the episode. ${ }^{23}$ Furthermore, unlike Candaules' wife, these women had no recourse to avenge their shame. Their powerlessness in the face of the transgression committed against them might have been the reason that made Herodotus choose their story to exemplify the hideous nature of tyranny (cf. 5.92ๆ4).

III.

Returning to the theme of death caused by a transgression, I will now consider the episode of the massacre of Dareios' ambassadors to the palace of Amyntas in Macedonia (5.18-20). ${ }^{24}$ In this episode, the young prince Alexander metes out a punishment of death on the Persian ambassadors who had offended the rules of hospitality by demanding the presence of Macedonian women at a banquet they attended. Their intention was to have a good time with the women, even after having been informed that local custom (nomos) demanded gender segregation at the table. The old Macedonian king did not want to defy the conquerors' authority and allowed the women of his house to join the guests. Alexander,

${ }^{20}$ On Greek funerary legislation, see Garland 1989.

${ }^{21}$ Cf. Diog. Laert. 1.96 with Gentili and Prato 2002: 21.

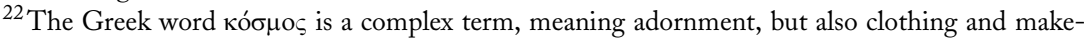
up and also the concepts of ornamentation and decoration (see Cleland, Davies, and Llewellyn-Jones 2007: s.v. kosmos).

${ }^{23}$ Pellizer (1993: 808-811) has also drawn attention for the implicit presence of the motif of

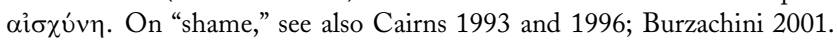

${ }^{24}$ For a detailed analysis of this episode, see Fearn 2007. 
however, decided to avenge the anomia committed by the ambassadors, causing them to be murdered by young men dressed up as girls. ${ }^{25}$ The killers displayed a double identity as both men and as transvestites (i.e., men disguised as women), ${ }^{26}$ their disguise facilitated by a very specific physical trait: a youthful face, whose lack of beard (ó $\alpha \delta \rho \alpha \varsigma \lambda \varepsilon 10 \gamma \varepsilon v \varepsilon i ́ o u \varsigma, ~ 5.20 .3)$ made it resemble a woman's. Under this illusory feminine appearance, the young men hid their true identity as men, along with their daggers, which Herodotus' readers would have immediately recognized as a masculine attribute.

It is interesting to note that this association of weapons with clothing and gender also appears elsewhere in the Histories. At 1.155, for instance, Croesus recommends to Cyrus that to avoid a possible rebellion from the men of Sardis

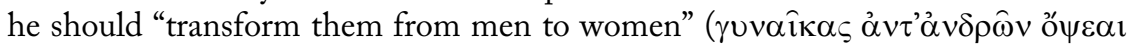
$\gamma \varepsilon \gamma o v o ́ \tau \alpha \varsigma, 1.155 .4)$ by making them dress as women while also denying them the use of weapons. In the episode of the Scythians and the Amazons, the Scythians have to uncover the corpses of the dead Amazons completely in order to realize that they are women (4.111.1). The men of Sardis are made to dress like women with the expectation that they will then act like women (and, in consequence, lose their value as warriors); the Amazons adopt not only male dress and accessories, but also behave like men (by hunting and fighting), and are as a result mistaken for men by their enemies. Like the story of the murdered Persian ambassadors, both these episodes involve a kind of transvestitism.

The story of the massacre of the Persian ambassadors shares structural themes with the stories of Greek and barbarian kings and tyrants we discussed above:

a) anomia: as in the stories of the sovereigns guilty of committing acts of hybris, the Persian ambassadors foolishly go against established local tradition, which in this case prohibited men mixing with women during a banquet; ${ }^{27}$

b) punishment: since foreign nomoi deserve the same respect as those at home, ${ }^{28}$ the anomia of the Persians is punished by death $;^{29}$

c) passion and death: the topos of the association between physical passion and death reappears, although here desire is stimulated by excessive drinking. The Persian ambassadors (like Periander with Melissa) wish to possess the

\footnotetext{
${ }^{25}$ Herodotus here uses terms with the generic sense of "dress" or "clothing" ( $\left.\check{\sigma} \sigma \dot{\eta} \varsigma, 5.20 .3\right)$, but he also specifically mentions that the clothes in question belong to women ( $\tau \hat{\omega} v \gamma v v \alpha \iota \kappa \hat{\omega} v, 5.20 .3)$

${ }^{26}$ Transvestitism played a part in several Greek rituals of initiation, i.e., rites of passage for boys on the threshold of reaching adult male citizenship; see Leitão (1995), who underlines the Greek, and also Aristotelian, idea that boys have "feminine" bodies, taking for feminine body a non-mature male body (157).

${ }^{27}$ In Fearn's interpretation, the complexity of this episode does not allow us to ascertain if the banquet was of Greek, Macedonian, or Persian nature. However, given the similarities between that episode and the Greek custom of segregation between genders, we can call it a "nearly-Greek banquet" (2007: 99).

${ }^{28}$ In 3.38.1 Herodotus recognizes ethnic tolerance, i.e., the respect for the foreign nomoi (in sacred matters as well as in all others), as an essential value in human nature.

${ }^{29}$ Fearn (2007: 106) gives a number of reasons why the act of revenge against the ambassadors was unjustified.
} 
bodies of the Macedonian women, but (like Candaules and Xerxes) they face a cunning opponent who is able to carry out an unexpected plan of revenge and murder; ${ }^{30}$

d) a metaphorical meaning assigned to the clothes being worn: at the fateful Macedonian symposium, those entrusted with performing the act of punishment were ordered by Alexander to dress in women's clothes ( $\delta$ 'A $A \lambda \varepsilon \dot{\varepsilon} \xi \alpha v \delta \rho o \varsigma$

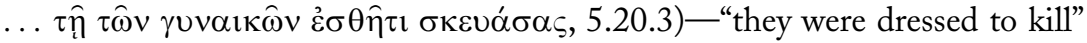
and they knew perfectly well their assigned roles. In the Xerxes story, on the other hand, Artaÿnte, with her public display of the royal cloak, "was dressed to die" and unaware that she was risking death (which she would have faced if the vengeful Amestris had followed the logical course of punishing the perpetrator-Artaÿnte - and not an innocent-Artaÿnte's mother).

There is one significant difference, however, between the Macedonian tale and the stories of Candaules and Xerxes. In the Macedonan tale the anomia is not produced by an act of "dressing" or "undressing." The chain of causation is reversed: here the clothes are not associated with anomia but with the act of revenge.

\section{CONCLUSION}

As literary paradigms, the Lydian Candaules, the Persian Xerxes, the Corinthian Periander, and the murdered Persian ambassadors emphasize the important role that both rules (nomoi) and the breaking of rules (anomia) play in the construction of the moral framework of the Histories. Occurring at key moments in the text-beginning, middle, and end - these stories using recurring leitmotifs of dress and undress demonstrate to Herodotus' audience that rules, human and divine, about female nudity and notions of hospitality, must be obeyed, by barbarians and Greeks alike.

Faculdade de Letras da Universidade de Coimbra

Largo da Porta Férrea

3004-530 COIMBra

Portugal

cilsoares@gmail.com

BIBLIOGRAPHY

Albaladejo Vivero, M. 2007. "Crueldad y violencia en los personajes femeninos de Heródoto," Emerita 75: 299-317.

Anhalt, E. K. 2008. "Seeing is Believing: Four Women on Display in Herodotus' Histories," New England Classical Journal 35: 269-280.

${ }^{30}$ I note here the motif of the male character, who, under the effect of alcohol, confuses men with women. The same situation can be found in Euripides' satirical drama Cyclops, a play in which the main character, Polyphemus, mistakes the chorus of Satyrs, Silenus' young sons, for the Graces (576-584) 
Blok, J. 2002. "Women in Herodotus' Histories," in E. J. Bakker, I de Jong, H. van Wees (eds.), Brill's Companion to Herodotus. Leiden. 225-242.

Burzachini, G. 2001. "Nudità e vergogna presso Lidi e barbari (Hdt. I, 10, 3)," Eikasmos 12: $85-88$.

Cairns, D. 1993. Aidos: The Psychology and Ethics of Honour and Shame in Ancient Greek Literature. Oxford.

— 1996. "'Off with her AI $\Delta \Omega \Sigma$ ': Herodotus 1.8.3-4," $C Q$ N.s. 46: 78-83.

Chiasson, C. C. 2003. "Herodotus' Use of Attic Tragedy in the Lydian Logos," CA 22: 5-35.

Cleland, L., G. Davies, and L. Llewellyn-Jones. 2007. Greek and Roman Dress from A to Z. London and New York.

de Romilly, J. 1971. La loi dans la pensée greque. Paris.

Desmond, W. 2004. "Punishments and Conclusion of Herodotus' Histories," GRBS 44: 19-40.

Dewald, C. 1997. "Wanton Kings, Pickled Heroes, and Gnomic Founding Fathers: Strategies of Meaning at the End of Herodotus' Histories," in D. H. Roberts, F. M. Dunn, and D. Fowler (eds.), Classical Closure: Reading the End in Greek and Latin Literature. Princeton. 62-82.

Evans, J. A. S. 1965. “Despotes nomos," Athenaeum 43: 142-153.

Fearn, D. 2007. "Narrating Ambiguity: Murder and Macedonian Allegiance (5.17-22)," in E. Irwin, E. Greenwood, A Study of the logoi in Book 5 of Herodotus' Histories. Cambridge. 98-127.

Flory, S. 1987. The Archaic Smile of Herodotus. Detroit.

Flower, M. 2007. "Herodotus and Persia," in C. Dewald and J. Marincola (eds.), Cambridge Companion to Herodotus. Cambridge University Press. 274-289.

— and J. Marincola (eds.). 2002. Herodotus: Histories, Book IX. Cambridge.

Garland, R. 1985. The Greek Way of Death. London.

— 1989. "The Well-Ordered Corpse: An Investigation into the Motives Behind Greek Funerary Legislation,” BICS 36: 1-15.

Gentili, B. and C. Prato. 2002. Poetae elegiaci testimoni et fragmenta. Editio altera, nouis Simonidis fragmentis aucta. Munich and Leipzig.

Gray, V. 2002. "Short Stories in Herodotus' Histories," in E. J. Bakker, I. de Jong, and H. van Wees (eds.), Brill's Companion to Herodotus. Leiden. 291-317.

Griffin, J. 2007. "Herodotus and Tragedy," in C. Dewald and J. Marincola (eds.), Cambridge Companion to Herodotus. Cambridge. 46-59.

Griffiths, A. 2007. "Stories and Storytelling in the Histories," in C. Dewald and J. Marincola (eds.), Cambridge Companion to Herodotus. Cambridge. 130-144.

Herington, J. 1991. "The Closure of Herodotus' Histories," ICS 16: 149-160.

Humphreys, S. C. 1987. "Law, Custom and Culture in Herodotus," Arethusa 20: 211-220.

Immerwahr, H. R. 1956-57. "The Samian Stories of Herodotus," CJ 52: 312-322.

Lateiner, D. 1984, "Herodotean Historiographical Patterning: The Constitutional Debate," QS 20: 257-284.

Leitão, D. 1995. "The Perils of Leukippos: Initiatory Transvestism and Male Gender Ideology in the Ekdusia at Phaistos," CA 14: 130-160.

Long, T. 1987. Repetition and Variation in the Short Stories of Herodotus. Beiträge zur klassischen Philologie 179. Frankfurt. 
Moles, J. 2007. “'Saving' Greece from 'Ignominy' and Tyranny? The 'Famous' and 'Wonderful' Speech of Socles (5.92)," in E. Irwin and E. Greenwood, A Study of the Logoi in Book 5 of Herodotus' Histories. Cambridge. 245-268.

Munson, R. V. 2001. “Ananke in Herodotus,” JHS 121: 30-50.

Ostwald, M. 1969. Nomos and the Beginnings of the Athenian Democracy. Oxford.

Pelling, C. 2002. "Speech and Action: Herodotus' Debate on the Constitutions," PCPS 48: $123-158$.

Pellizer, E. 1993. "Periandro di Corinto e il forno freddo," in R. Prestagnosti (ed.), Tradizione e innovazione nella cultura greca da Omero all'età ellenistica: sciti in onore di Bruno Gentili 2. Rome.

Rocha Pereira, M. H. 1990. “O 'Diálogo dos Persas' em Heródoto," Estudos portugueses: Homenagem a António José Saraiva. Lisbon. 351-362.

Sancisi-Weerdenburg, H. 1983. "Exit Atossa: Images of Women in Greek Historiography on Persia," in A. Cameron and A. Kuhrt (eds.), Images of Women in Antiquity. London and Canberra.

Soares, C. 2014. "Theoria e práxis política em Heródoto," Cuadernos de Filología Clássica: Estudios griegos e indoeuropeus 24: 57-79.

Travis, R. 2000. "The Spectation of Gyges in P. Oxy. 2382 and Herodotus Book 1," CA 19: 330-359.

van Wees, H. 2010. "Trailing Tunics and Sheepskin Coats: Dress and Status in Early Greece”, in L. Cleland, M. Harlow, and L. Llewellyn-Jones (eds.), The Clothed Body in the Ancient World. Oxford. 44-51.

Wagner-Hasel, B. 2002. "The Graces and Colour Weaving," in L. Llewellyn-Jones, Women's Dress in the Ancient Greek World. London. 17-32.

Waters, K. H. 1971. Herodotos on Tyrants and Despots: A Study in Objectivity. Historia Einzelschriften 15. Wiesbaden.

Wolff, E. 1964. "Das Weib des Masistes," Hermes 92: 51-58 (repr. with alterations in W. Marg [ed.], Herodot. Eine Auswahl aus der neueren Forschung ${ }^{3}$ [Darmstadt 1982] 661-678). 